\title{
Культурологія
}

УДК 140.8:304.2(477)

\author{
Борейко Юрій Григорович \\ доктор фрілософських наук, доцент, \\ завідувач кафедри філософії та релігієзнавства \\ Східноєвропейського національного університету \\ імені Лесі Українки \\ ORCID 0000-0002-0786-8764 \\ yboreiko71@gmail.com
}

\section{ІНТЕРПРЕТАЦІЯ КУЛЬТУРНОЇ ПОДІЇ В УМОВАХ СОЦІАЛЬНИХ ЗМІН: УКРАЇНСЬКИЙ ВИМІР}

\begin{abstract}
Метою дослідження є визначення смислового потенціалу інтерпретації культурної події в сучасному українському суспільстві в умовах соціальних змін з урахуванням здатності соціокультурних наративів конструювати різні варіанти сприйняття дійсності. Методологія дослідження ґрунтується на використанні методів герменевтичної інтерпретації (для з'ясовання смислів і значення культурної події), компаративного аналізу (з метою порівняння змісту та контексту створення соціокультурних наративів), структурно-функціонального методу (для розкриття значення культурної події у функціонуванні соціальних інститутів). Наукова новизна отриманих результатів полягає у виявленні наслідків конфллікту інтерпретацій культурних подій в українському суспільстві, що супроводжується неадекватною символізацією опису подій, вибірковістю понять, комбінаціями висловлювань, протиборством концептів заангажованих ідеологічними установками, власними чи корпоративними інтересами інтерпретаторів. Висновки. В умовах соціальних потрясінь культурні події стають точкою перетину різноманітних інтерпретацій. Соціокультурний наратив спрямований не лише на пошук і визначення сенсів, конструювання сценаріїв поведінки суб'єктів, а й має визначальний вплив на вектор розвитку суспільства, формування суспільного дискурсу. Оскільки кожен соціокультурний наратив претендує на винятковість, включаючи переконання про правильність власного варіанту розуміння подій, неминучим $€$ зіткнення наративів та їх інтерпретацій, що перетворюється на конфлікт свідомості й пам'яті представників різних поколінь або світоглядів.
\end{abstract}

Ключові слова: культурна подія, наратив, інтерпретація, криза, суб'єкт, суспільство, трансформація.

Борейко Юрий Григорьевич, доктор философских наук, дочент, заведующий кафедрой философии и религиоведения Восточноевропейского национального университета имени Леси Украинки

Интерпретация культурного события в условиях социальных изменений: украинское измерение

Целью исследования является определение смыслового потенциала интерпретации культурного события в современном украинском обществе в условиях социальных изменений с учетом способности социокультурных нарративов конструировать различные варианты восприятия действительности. Методология исследования основана на использовании методод герменевтической интерпретации (для выяснения смыслов и значения культурного события), компаративного анализа (с целью сравнения содержания и контекста создания социокультурных нарративов), структурно-функционального метода (для раскрытия значения культурных событий в функционировании социальных институтов). Научная новизна полученных результатов заключается в выявлении последствий конфликта интерпретаций культурных событий в украинском обществе, сопровождающегося неадекватной символизацией описания событий, избирательностью понятий, комбинациями высказываний, противоборством концептов ангажированных идеологическими установками, собственными или корпоративными интересами интерпретаторов. Выводы. В условиях социальных потрясений культурные события становятся точкой пересечения различных интерпретаций. Социокультурный нарратив направлен не только на поиск и определение смыслов, конструирование сценариев поведения субъектов, но и имеет определяющее влияние на вектор развития общества, формирования общественного дискурса. Поскольку каждый социокультурный нарратив претендует на исключительность, включая убеждение о правильности собственного варианта понимания культурных событий, неизбежным является столкновение нарративов и их интерпретаций, превращающееся в конфликт сознания и памяти представителей разных поколений или мировоззрений.

Ключевые слова: культурное событие, нарратив, интерпретация, кризис, субъект, общество, трансформация.

Boreiko Yurii, Doctor of Philosophical Sciences, Docent, Head of the Department of Philosophy and Religious Studies of the Lesya Ukrainka East European National University

Interpretation of a cultural event in conditions of social changes: Ukrainian dimension

The purpose of the article is to determine the semantic potential of interpreting a cultural event in contemporary Ukrainian society in conditions of social change, taking into account the ability of socio-cultural narratives to construct different versions of perception of reality. The methodology is based on the use of hermeneutic interpretation methods (to clarify the meanings and significance of a cultural event), comparative analysis (to compare the content and context of the creation of socio-cultural narratives), structural and functional method (to reveal the significance of a cul-

(c) Борейко Ю. Г., 2020 
tural event in the functioning of social institutions). The scientific novelty of the results obtained is to identify the consequences of the cultural events interpretations' conflict in Ukrainian society, which is accompanied by inadequate symbolization of the description of events, the selectivity of concepts, combinations of statements, confrontation of concepts engaged by ideological settings, own or corporate interests of interpreters. Conclusions. In conditions of social upheaval, cultural events become the point of various interpretations intersection. The socio-cultural narrative is aimed not only at the search and definition of meanings, the construction of the subjects' behavior scenarios, but also has a decisive influence on the vector of society development, the social discourse formation. Since every socio-cultural narrative claims to be exceptional, including the belief in the correctness of its own version of the understanding of the events, the narratives' collision and their interpretations, which becomes a conflict of consciousness and memory of different generations or worldviews representatives, is inevitable.

Key words: cultural event, narrative, interpretation, crisis, subject, society, transformation.

Актуальність теми дослідження. На сучасному етапі українське суспільство переживає ціннісно-нормативний вакуум, що притаманний розвитку суспільств з перехідними кризовими періодами. Трансформаційні процеси детермінують режими функціонування суспільства, супроводжуються зміною способу життя, ставлення до світу, переглядом цінностей, орієнтацій та установок суб'єктів. За таких умов поширюються наративи, які інтерпретують появу нових культурних фрорм, артефрактів, подій залежно від ракурсу, точки зору або кількох планів чи горизонтів тлумачення. Врахування смислового потенціалу соціокультурного наративу у площині подія - наратив - інтерпретація дає змогу з'ясувати особливості інтерпретації культурних подій в умовах соціальних змін, які, з одного боку, актуалізують усталені світоглядні уподобання, з іншого - конструюють нові інструменти осмислення реальності.

Аналіз досліджень і публікацій. Визначеня події, встановлення її місця та ролі в суспільному житті, способи інтерпретації події є предметом поспійної уваги дослідників. Так, С. Жижек, убачає в події новацію, яка не вписується в усталені уявлення,і не збігається із попереднім досвідом та призводить до трансформації звичного життя. Витоки події можуть мати трансцендентне походження або бути вкоріненими в бутті людини [12].

Культурна подія як різновид соціальних подій є об'єктом зацікавлення науковців у поєднанні 3 перебігом культурного процесу. Розуміючи культурний процес як взаємодію в рамках елементів, що належать до класу культурних явищ, Р. Карнейро вважає подію складовою перебігу великого і єдиного процесу, який охоплює всі культурні традиції в усі періоди і на всіх територіях [2, 423-424].

Здатність до модифікації події з метою створення відчуття присутності в теперішньому часі має наратив як універсальна характеристика культури. Саме теперішнє, за П. Рікером, є місцем зустрічі пам'яті з інтенціями майбутнього [7]. 3 іншого боку, внаслідок появи суперечливих тлумачень події, зокрема, у зв'язку з відмінністю смислів, застосування яких залежить від контексту, виникає конфрлікт інтерпретацій [6].

Для позначення певних суспільних явищ та їхнього сумарного вектору вчені використовують термін «криза», що означає розлад, дисфункціональність у політичній, економічній, культурній сферах [11]. Криза має тотальний характер, зумовлює брак концептів для адекватної оцінки її масштабів та забезпечення ефективної протидії.

Зміни, які відбуваються в українському суспільстві вчені визначають як стан сингулярності, що поєднанує кризу в економіці, виключність - у політиці та надзвичайність (emergency) - в культурі. «Emergency» в культурі означає зміни в ціннісно-нормативних структурах, динаміці культурних практик, ідентичності, політиці пам'яті [8]. Стан «еmergency» має експансивний характер, передбачає декларування нових пріоритетів розвитку, впливає на спосіб житя людей шляхом вимушених і випереджувальних реакцій [3].

Як бачимо, кризові явища в суспільстві продукують, з одного боку, невизначеність, відсутність довіри до соціальних інституцій, з іншого - детермінують виникнення та інтерпретацію різноманітних подій. Необхідність пояснення причин та наслідків культурних подій зумовлює потребу в створенні та поширенні соціокультурних наративів, проблема інтерпретації яких в умовах кризи потребує подальшого дослідження.

Метою статті є з'ясування смислового потенціалу інтерпретації культурних подій у сучасному українському суспільстві, яке характеризується вираженими трансформаційними процесами, 3 урахуванням здатності соціокультурних наративів конструювати різні варіанти сприйняття дійсності.

Виклад основного матеріалу. Дослідження сучасного культурного простору передбачає концептуальне осмислення його динамічних процесів, які, поряд зі зміною культурних систем та об'єктів, можна розглядати як типові конструкти або моделі взаємодії між суб'єктами і соціальними групами. Йдеться про стійкі у повторюваності та типові й універсальні за ареалом поширення в різних культурах функціональні процедури, які можна класифікувати на основі спільних ознак.

Культурні процеси виявляються у множині культурних подій, які виступають конкретноісторичними виявами перебігу культурних процесів. Самі ж культурні процеси мають унікальні риси, варіативність котрих визначається умовами та обставинами здійснення. Тобто культурний процес «запускається» культурною подією, проте функціонує за власною логікою. Культура делегує процесу 
певні властивості, які забезпечують йому причетність або належність до культури. Отже, у структурі культурного процесу подія виступає конкретним проявом варіативного багатоманіття.

У процесі аналізу кризового стану суспільства увага вчених акцентується на позитивних конотаціях змісту поняття «криза», зокрема на оптимістичних змінах, які мають ознаки відновлення та креативності [10]. Результатом кризи часто стає перехід у якісно новий стан, тобто заміна застарілих соціальних структур новими, які $є$ більш адекватними вимогам суспільства. Оскільки криз неможливо уникнути, слід регулювати їх функціональні вияви та зменшувати руйнівні наслідки. На переконання Н. Костенко, криза передбачає інституційні режими пом'якшення та контролю [3].

Зауважимо, що перебування українського суспільства у нинішньому стані системної турбулентності підпадає під визначення стану «emergency», який виражається у зростанні соціальної невпевненості, змінах у способі життя людей, трансформації суспільних порядків, що, безперечно, має наслідки у культурному житті. За оцінкою вчених, стан «еmergency» «не виключає ризику перетворитися на константу, оскільки культура «emergency» транслюється на спосіб життя людей, іхні інтуїції, наміри й дії, і відчутні вібрації загального та приватного існування не дозволяють довіритися будь-чиїм (інституціональним і персональним) гарантіям із приводу його імовірної тривалості» $[5,6]$.

За таких обставин відбуваються процеси сприйняття та інтерпретації культурних подій, ідентифрікації, «перекодування» символів, осмислення сутнісних ознак та функцій культурних явищ, символічного «привласнення» та формування нормативних варіантів їх інтерпретації, культурних форм, за допомогою яких здійснюється самоідентифікація суб'єктів, символізації простору проживання, перетворення стереотипів сприймання й інтерпретації на важливу складову культурної традиції [4]. Під впливом культурних подій модифікуються соціальні та ментальні структури, стандарти, критерії оцінки, поширюються індивідуальні та групові інтенції, очікування, переживання.

Особливістю стану «еmergency» $€$ необхідність, з одного боку, адаптації до нових умов, з іншого - уникнення чи протидія доступними способами. Варіантом можливих дій є індивідуальна і колективна участь у проектуванні якщо не істотних, то хоча б часткових змін. Стан «еmergency» продукує дію, яка розглядається як засіб зниження невизначеності, перешкода потенційному погіршенню ситуації. Проте дія може бути спрямована на відсторонення від ситуації та зосередження на особистих проблемах. Скупчення невизначеностей у стані «еmergency» мають здатність нашаровуватися, утворюючи присутність різноманітних суб'єктів, речей, подій [3].

Обгрунтовуючи гіпотезу про історичні події як культурні артефакти, А. Флієр акцентує увагу на культурній зумовленості соціальної активності людини та детермінованості її поведінки культурним контекстом. Подія включає виклик, що породжує потребу у відповіді і саму відповідь (адаптацію) спільноти на виклик, який може мати як зовнішній характер (напад ворога, кліматична катастрофа), так і бути результатом внутрішнього розвитку (поява нових технологій). Різні народи по-різному відповідають на виклики - борються, мігрують, щось винаходять, тобто адаптуються в нових умовах або змінюють середовище. Незалежно від глобального чи локального характеру викликів відповідь на них детермінується особливостями культури народу, його історичним досвідом, специфікою національного характеру. В такий спосіб події (відповіді на виклики) набувають культурної зумовленості [9].

Безперечно, у період соціальних трансформацій відбувається мобілізація частини пересічних громадян, які ставлять за мету допомогти суспільству вирішити конкретні проблеми, що можна розцінювати як солідарність або емпатію. В українському суспільстві про це свідчать різноманітні гуманітарні ініціативи, зокрема розгортання з початком війни на сході країни волонтерського руху, що набув рис оригінального соціокультурного френомену.

Трансформаційні процеси у суспільстві детермінують, з одного боку, особливості сприйняття соціальної дійсності, з іншого - специфіку конструювання наративів, основна мета функціонування яких полягає в обґрунтуванні та поясненні певних явищ і подій культурного життя. Основними ознаками наративу $є$ наявність кінцевої мети оповіді, відбір найважливіших подій, упорядкованість подій у певній часовій послідовності. Тобто наратив перетворює невпорядковані події у певну послідовність на основі створеного міфу або бачення оповідача, що й фрормує внутрішню логіку оповіді. Ключові смисли наративів розуміють носії культури, що свідчить про ступінь їх соціалізації та рівень мовної компетенції.

Намагаючись осмислити й описати свій досвід, суб'єкт використовує зафіксований у засобах культури сюжет - історичний, міфологічний, архетипний, літературний, який упорядковує інфрормацію про подію. Суб'єкт накладає цей наратив у вигляді інтерпретаційних рамок на дійсність, що осмислюється. Іншими словами, наративізація є механізмом, який дає змогу трансформувати культурні події у досвід суб'єкта шляхом їх упорядкування. Інтерпретація події передбачає виокремлення ії зовнішньої та внутрішньої граней, які розглядаються у тісному взаємозв'язку. Зовнішня оболонка стосується фрізичних процесів, натомість вивчення внутрішнього змісту події передбачає співвіднесення його із соціальним контекстом.

Об'єктивний аспект значущості культурної події визначається збереженням її результатів незалежно від особливостей тлумачення, проте за певних обставин важливі події сьогодення і минулого породжують конфлікт інтерпретацій. Оскільки нинішній стан українського суспільства зумовлений не лише наслідками об'єктивних суперечностей, а й свідомим втручанням та поглибленням ззовні, на 
соціокультурний наратив покладено функцію протидії зовнішнім інформаційно-комунікативним впливам. Так, в рамках інтерпретації наративу про хрещення 988 року як події, що засвідчує спільну «купіль трьох братніх народів», російська пропаганда обґрунтовує відкриття у Москві пам'ятника київському князю Володимиру як новітній артефакт, який підтверджує спільну культурну спадщину Київської Русі.

Прикметно, що смисловий потенціал культурно детермінованих наративів може коливатися від свідомого нехтування поміркованою інтерпретацією до загострення уваги на її полюсах з метою поляризації публічного дискурсу. Зі свідомістю масових споживачів здійснюються відверті маніпуляції, що призводить до зміни модальності події, тоді як підготовленій публіці пропонуються протилежні підходи альтернативних інтерпретаторів. Іншими словами, за певних обставин наратив впливає на оцінку подій з віддаленої від реальності, однобічної чи спрощеної позиції.

Ускладнюють ситуацію стереотипи й упередження суб'єктів, оскільки фрормують їх позицію у соціальному просторі, задаючи певний кут зору для сприйняття інформації про культурну подію. Відтак адекватне й помірковане вивчення контексту події є компетенцією фахівців, натомість інтерпретація події на злобу дня часто має тенденційний характер. Не випадково Ф. Бродель наголошував на необхідності певного проміжку часу від події до її осмислення, аби мати змогу «вирватися з полону подій, щоб знову повернутися до них і поглянути на них іншими очима, поставити їм інші запитання» $[1,141]$.

Отже, в умовах соціальних трансформацій функціонують соціокультурні наративи, поширення та інтерпретація яких передбачає застосування маніпулятивних прийомів для формування альтернативної реальності, стану контрольованого хаосу з метою досягнення певних цілей. У цій ситуації навіть особам, які аналізують інформацію, подекуди важко розібратися, в якому випадку йдеться про реальність, а коли подається вигадка. За визначенням П. Рікера, інтерпретація - це робота мислення над розшифруванням смислу, який міститься в очевидному значенні. Прихований зміст, який слід інтерпретувати, значною мірою залежить не лише від контекстуального наповнення вихідного повідомлення, а й від складності та різноманітності значеннєвої сфери споживача, що дає змогу по-різному осмислювати початкове повідомлення з огляду на здатність до аналізу та його коректного застосування [7].

Адаптація культурної події до соціальних умов відбувається у вигляді символізації як процесу створення на абстрактно-узагальненому рівні понять, що є аналогом для заміщення явища або процесу, а також в узагальненому вигляді концентрують їх специфічні ознаки. Вживаючи ці поняття в усній чи письмовій формах, оповідач апелює не до одиничної події, а наголошує на масштабності предмета осмислення. Ці поняття є не лише носіями певних значень, а виступають індикатором, що орієнтує суб'єкта на значущість контексту, який має бути не лише сприйнятий, а й потребує осмислення та інтерпретації. Так, використання понять «українізація», «сакралізація», «діджиталізація» тощо навіть без звернення до конкретних прикладів передбачає виокремлення оціночного компоненту. Iншими словами, представники певної культурної епохи сприймають значення цих понять не лише як сукупність узагальнених рис, а як категорію, що містить позитивний або негативний маркер.

Серед численних способів адаптації наслідків культурної події до соціальних умов вирізняються використання ритуалів, свят, переписування підручників історії, просування політики памяті, заперечення, витіснення та відбір інформації з метою коригування ставлення до фрактів, явищ, процесів. Ілюстрацією боротьби за інтерпретацію події є поширення наративів з приводу утворення Православної церкви України та надання їй автокефалії, що спричинило у суспільстві неоднозначне трактуванням цих подій - від обгрунтування втручання держави у церковні справи до твердження про автокефалію як можливість досягнення єдності й визнання української церкви світовим православ'ям.

Як бачимо, інтерпретація соціокультурних наративів в умовах резонансних культурних подій може супроводжуватися неадекватною символізацією їх опису, вибірковістю понять, комбінаціями висловлювань, протиборством концептів заангажованих ідеологічними установками, власними чи корпоративними інтересами інтерпретаторів.

Висновки. Таким чином, соціальні потрясіння, що спостерігаються в українському суспільстві, крім різноманітних виявів криви, супроводжуються станом надзвичайності в культурі, який характеризується антиномічними ціннісними орієнтаціями, крайньою політизованістю або демонстративною аполітичністю, секуляризацією або сакралізацією духовного життя, тобто супроводжуються подіями, що набувають певного статусу для конкретного суб'єкта лише після інтерпретації. Створюючи новий смисловий контекст, інтерпретація здатна передавати сутність того, що виникло під впливом множини явищ, котрі трактуються суб'єктом як культурна подія. Призначення соціокультурного наративу як способу наближення суб'єкта до реальності полягає у з'ясуванні значення події для подальшого існування людини чи суспільства.

\section{תimepamypa}

1. Бродель Ф. История и общественные науки. Историческая длительность. Философия и методология истории / под. ред. И.С. Кона. М.: РИО БГК им. И. А. Бодуэна де Куртенэ. 2000 (переиздание 1963). С. 115-142. 
2. Карнейро Р. Культурный процесс / пер. с англ. П. Резвых. Антология исследований культуры: в 3 т. Т. 1. Интерпретация культуры. СПб: Университетская книга, 1997. С. 421-438.

3. Костенко Н. У стані «еmergency»: культурні ефекти. Соціологія: теорія, методи, маркетинг. 2016. № 4. C. $102-118$.

4. Культурология. $\mathrm{XX}$ век: в 2 т.: энциклопедия. Т. 1 / гл. ред. и сост. С.Я. Левит. СПб.: Университетская книга; ООО «Алетейя», 1998. 447 с. 2015. $440 \mathrm{c}$

5. Мінливості культури: соціологічні проекції / за ред. Н. Костенко. К. : Інститут соціології НАН України,

6. Рикер П. Конфрликт интерпретаций. Очерки о герменевтике / пер. с фр. вступ. ст. и коммент. И.С. Вдовиной. М.: Академический Проект, 2008. 695 с.

7. Рікер П. Історія та істина / пер. з франц. В.І. Шовкуна. К.: КМ Academia Пульсари, 2001. 393 с.

8. Стан сингулярності: соціальні структури, ситуації, повсякденні практики / за ред. С. Макеєва і С. Оксамитної. К.: НаУКМА, 2017.

9. Флиер А.Я. Интерпретация смысла истории: событие как культурный артефакт. Знание. Понимание. Умение. 2017. № 4. С. 98-107.

10. Bauman, Z., \& Bordoni, C. State of Crisis. Cambridge: Polity Press, 2014. 164 p.

11. Walby S. Crisis. Cambridge: Polity Press, 2015. 224 p. 2014. $192 \mathrm{p}$.

12. Zizek S. Event: A Philosophical Journey Through A Concept. London: Penguin Books LTD, Melville House,

\section{References}

1. Brodel, F. (2000). History and social sciences. Historical duration. Philosophy and methodology of history. I.S. Kon (Ed.). (1963 reissue). Moscow: RIO BGK im. I. A. Boduena de Kurtene, 115-142 [in Russian].

2. Carneiro, R. (1997). Cultural process. Anthology of cultural studies. (P. Rezvykh, Trans.). (Vols. 1-3). St. Petersburg: Universitetskaia kniga, 421-438 [in Russian].

3. Kostenko, N. (2016). In the state of «emergency»: cultural effects. Sociologhija: teorija, metody, marketyngh, 4, 102-118 [in Ukrainian].

4. Culturology. The twentieth century: encyclopedia. (1998). Levit, S. Ya. (Eds.). (Vols. 1-2). St. Petersburg: Universitetskaia kniga; OOO «Aleteiia» [in Russian].

5. Kostenko, N. (Ed.). (2015). The variability of culture: sociological projections. Kyiv: Instytut sociologhiji NAN Ukrajiny [in Ukrainian].

6. Riker, P. (2008). Conflict of interpretations. Essays on hermeneutics. (S. Vdovina, Trans.). Moscow: Akademicheskii Proekt [in Russian].

7. Ricker, P. (2001). History and truth. (V. I. Shovkun, Trans.). Kyiv: KM Academia Puljsary [in Ukrainian].

8. Makeiev, S., \& Oksamytna, S. (Eds.). (2017). The state of singularity: social structures, situations, everyday practices. Kyiv: NaUKMA [in Ukrainian].

9. Flier, A.Ya. (2017). Interpretation of the meaning of history: event as a cultural artifact. Znanie. Ponimanie. Umenie, 4, 98-107 [in Russian].

10. Bauman, Z., \& Bordoni, C. (2014). State of Crisis. Cambridge: Polity Press [in English].

11. Walby, S. (2015). Crisis. Cambridge: Polity Press [in English].

2. Zizek, S. (2014). Event: A Philosophical Journey Through A Concept. London: Penguin Books LTD, Melville House [in English].

Стаття надійшла до редакції 6.09.2019 p. Прийнято до публікації 4.10.2019 р. 